\author{
Adam Krystian Wiśniewski ${ }^{1}$ \\ Department of Organization and Management, Faculty of Economic Sciences \\ University of Warmia and Mazury in Olsztyn
}

\title{
The specificity of the functioning of the volleyball club in the aspect of creating a business model
}

\begin{abstract}
This study is the basis for theoretical considerations on the functioning of volleyball club business models. The analyzed object is Piłka Siatkowa AZS UWM S.A. in Olsztyn, operating under the Indykpol AZS Olsztyn brand. In the described case, an analysis of the functioning of the volleyball club functioning at the highest league level was made. The article discusses the construction of a volleyball club in accordance with the requirements of the organizer of the competition. The aim of the study was also to identify and analyze the management methods of the sports club in the context of the available budget, its components and organizational structure. The study was conducted using the monographic method, in which the interview was used, supplemented with the analysis of documents and information obtained from the Profesjonalna Liga Piłki Siatkowej S.A. and Piłka Siatkowa AZS UWM S.A. The research also focuses on the comparison of the current situation with the results obtained in 2013 and presented in the study entitled Management of the Sports Club on the example of Indykpol AZS Olsztyn.
\end{abstract}

Keywords: business model, volleyball, sport club, AZS Olsztyn

\section{Admission}

Volleyball clubs in Poland run in a professional manner and constitute, next to football, the best functioning branch of national sport. By developing the requirement to adopt the personality of the companies, they normalized and standardized their activities. Among the aspects of professionalization, two main characteristics were distinguished: commercialization and globalization. In both cases, actions taken by decision-makers in volleyball clubs strive to maintain interest in the products they offer ${ }^{2}$.

This paper is the basis for theoretical considerations on the functioning of volleyball clubs business models. The analyzed object is Piłka Siatkowa AZS UWM S.A. in Olsztyn, operating under the Indykpol AZS Olsztyn brand. In the described case, an analysis of the functioning of the volleyball club functioning at the highest league level was made. The paper discusses the construction of a

\footnotetext{
${ }^{1}$ mgr Adam Wiśniewski, e-mail: adam.wisniewski@uwm.edu.pl

${ }^{2}$ Understood as both products and services
} 
volleyball club in accordance with the requirements of the organizer of the competition. The aim of the study was also to identify and analyze the management of the sports club in the context of the available budget, its components and organizational structure. The study was conducted using the monographic method, in which the interview was used, supplemented with the analysis of documents and information obtained from the Profesjonalna Liga Piłki Siatkowej S.A. (PLPS) and Piłka Siatkowa AZS UWM S.A. The survey will also focus on the comparison of the current situation with the results obtained in 2013 and presented in the study entitled Management of the Sports Club on the example of Indykpol AZS Olsztyn.

\section{Business model of a volleyball club}

The creation of business models has been gaining popularity among theoreticians and management practitioners in recent years. Starting from the 1950s, when the first applications of the concept of business model were noted, they were developed over the years and reached its apogee at the turn of the century. Along with the progress of globalization and the popularization of access to electronic media and information exchange platforms, there has been a forced progress in the approach to managing organizations. Managers forced to look for new solutions have attempted to systematize the specificities and areas differentiating the patterns of enterprises operating on the common market. Business models proved to be easy, which in essence "reflect the fragment of reality that interests us, omitting less important elements of this reality" (Sadowski, 1964).

The concept of business models describes the desire to create the maximum value for both the customer and the company offering it. This was emphasized by a number of authors, among which one can distinguish the statement that it is a system created to create value through the exploitation of business opportunities (Amitt, Zott 2001). "The business model is a conceptual tool expressing the company's business logic and containing a set of objects, concepts and their relationship with the goal." The model captures a description of value directed to one or several customer segments, company architecture, partner networks in value creation, value delivery methods, relational capital and sustainable income streams "(Osterwalder, Pigneur, Tucci, 2005). Sz. Cyfert and K. Krzakiewicz point out that the business model "defines the logic of connections between the resources at the disposal of the organization and the activities that create value for the broadly understood customers" (Cyfert, Krzakiewicz, 2011). Thus, it can be stated that the business model helps to describe, characterize and analyze the areas of functioning and the environment of a given organization and specify potential sources of competitive advantage by means of a definable bundle of offered value for the customer and the value captured by the company. 


\section{Components of the business model}

The business model definitions proposed by the authors diverge in many aspects. There is no one widely recognized definition of a business model. For this reason, there is also one common classification of its components. Most authors as a starting point admit the discussed aspect of value creation. N. Vankatraman and J.C. Henderson lists as components of the client's business model, asset and knowledge (Vankatraman, Henderson 1998), P. Weill and M.R. Vitale exchanges consumers, allies, suppliers and streams of information and money products (Weill, Vitale, 2001). J. Magretta focuses on values for customers, production costs, basic economic logic, supplying value to clients and the value chain (Magretta 2002). A. Afuah and Ch.L. Tucci (2001) specify the value offered to clients, the scope of the offer, pricing policy, sources of revenues, related activities, methods of model implementation, company skills and durability of competitive advantage. M. Muszyński, in turn, lists the added value, the place where the revenues are created and the value chain (Muszyński 2006). B. Nogalski, as the components of the business model, lists the value offered to clients, basic resources and activities as well as relations with partners (Nogalski 2009). S. Cyfert and K. Krzakiewicz provided a detailed list of components of the business model: business domain, value proposition, distribution channels, customer relations, revenue streams, key resources, key activities, key partners and cost structure (Cyfert, Krzakiewicz 2011). Discrepancies in the level of specification of components and their scope make it difficult for management practitioners to take one model for implementation and before the theoreticians poses a challenge to present their own elementary definitions of the business model. Among other things, for this reason, based on the research carried out so far, the author has adopted an eight-element specification of the components of the business model. It includes: value for the client, value for the generating enterprise, relations, competences, distribution channels, resources, instruments of competition and methods of creating value.

\section{The specifics of volleyball clubs}

Due to the importance of focusing around elements that translate into the company's ability to create value, it is necessary to accurately analyze the specifics of the industry being undertaken. In the case of sport, it is necessary to clarify a few basic issues related to it. This commercialization and professionalization entitle the perception of sport as one of the elements of the economy that generate significant revenues for both the enterprise and the state budget. The professionalization criterion, in turn, may be considered by the aspect of club organization. The matches and leagues of clubs operating as joint-stock companies will be considered professional. Other organizations participating in the competition are considered semi-professional clubs, they operate in the form of a physical culture association.

Volleyball in Poland was one of the first disciplines to become professional. The beginning of professional volleyball in Poland can be considered the year 2000 when the PLPS raised and its shareholders were ten teams of the then 
Series A and the Polish Volleyball Federation (PZPS). Until today, PLPS carries out tasks consisting mainly in earning money for clubs, representing them, acquiring sponsors and signing media contracts. In the same year, volleyball was granted a license for professional competitions, organization of league matches and the Cup tournament named Puchar Polski.

Sports organizations pursue two goals: business and sport. Business, according to the classic approach, are related to the achieved financial result. Sports focus on the results achieved in participating competitions. Volleyball clubs operating on professional business principles must take into account a much wider aspect of customer needs. They differ from traditional business organizations by offering a bundle of emotions. The basic product of the volleyball club is the match. Players are recruited, trained and coached in one basic goal - to play a match and score points for classification. In recent years, the match has "grown" to the rank of spectacle, during which the client (viewer) recieves as many elements as possible that affect his emotions. It is important for club managers that the sporting spectacle is essentially unpredictable. The client wants to participate in it without knowing what the course will take and what will end with the result.

In this case, the organization faces two tasks:

1. Creating and delivering identified and consciously expected values by the client.

2. Creating and proposing values that the client has not expressed and for which he is willing to pay.

A proper combination of these activities will allow the club to attract and retain the client and, consequently, strengthen its competitive position.

The second distinctive feature of volleyball clubs (and generally sports organizations) are business opportunities, which are conditioned on the volume of financing sources. Unlike traditional business organizations, volleyball clubs are much more likely to be exposed to the risk of changing club financing. This causes fluctuations in the organization's functioning aspects and its sporting effectiveness. As a result, managers are forced to work definitely more in a short-term and reactive manner than in traditional business organizations. Success in this case may depend on the club's ability to build lasting relationships with partners and sponsors.

\section{Analysis of changes in the organization of the volleyball club}

Work on the aspects of building a volleyball club business model should be embedded in permanent conditions and specifics of a single club and the entire industry. For the sake of this aspect, the author decided to carry out a re-examination of the functioning of the volleyball club and to compare and specify possible changes that have occurred over the past few years. The starting point is the data obtained during the research carried out in 2013 and published in the article Sports Club Management on the example of Indykpol AZS Olsztyn. They will be confronted with information obtained from the same unit in 2017. In the study from four years ago the following aspects were specified: organizational structure, participation in the competition, infrastructure, sources of financing and their structure as well as seasonality. They will be compared to the current situation of the 
volleyball club.

\section{Organizational structure}

The organizational structure examined in 2013 was characterized by a clear division of the club into the sports division and the organizational division. This allowed for a quick flow of decisions and information between decision-makers and the implementation of the proposed plans.

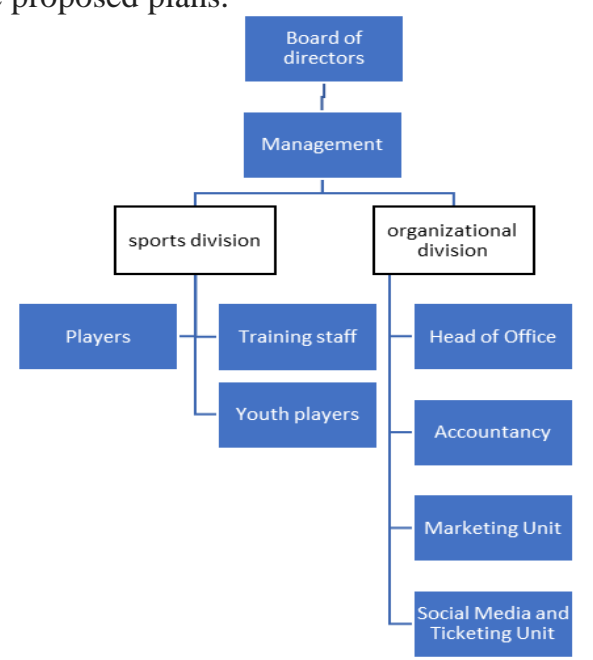

Figure 1. Organizational structure of Indykpol AZS Olsztyn in 2013

Source: Wiśniewski A.K., Sports Club Management on the example of Indykpol AZS Olsztyn, Journal of Health Sciences. 2013, Vol. 3(11), pp. 173.

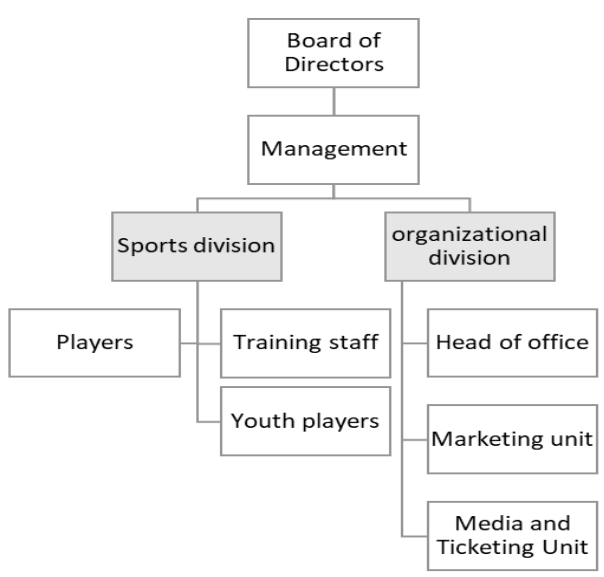

Figure 2. Organizational structure of Piłka Siatkowa AZS UWM S.A. in 2017 Source: Own elaboration 
The main change in the company's organizational structure is the separation and transfer of accounting responsibilities to an external company. Significant changes were not recorded in the number of employees. The organizational division "employs" three people. The Management Board consists of one person - the President. There are five people in the Supervisory Board. The composition of the sports division depends mainly on the requirements of the league authorities. In the 2016/2017 season, the team consisted of eighteen competitors and six employees of the training staff (in the 2013/2014 season it was respectively fifteen and six employees). The requirements of the organizer of the competition result in the obligation to lead the team and participate in the caves of the so-called "Youth League". Compared to 2013, the number of competitors decreased by four (to twenty) and the number of members of the training staff (three people) did not change. Over the years, the organization of work has not changed. Employees have considerable autonomy of actions, subordinated to their ability to achieve goals. The control and evaluation of the work is carried out on the basis of the results achieved. This seems to be confirmed in the theoretical studies on management in sport, as already in $2000 \mathrm{~J}$. Klisiński stated that "the basic goal of sport management is to create the necessary conditions (organizational, technical, social, psychological, etc.) to perform tasks in sport and coordinate and agreeing on the way employees work to achieve specific, planned results" (Klisiński 2000).

\section{Participation in the competition}

The conditions for participation in competitions are regulated by the Professional Volleyball Competition Regulations. The last version, adopted in March 2017 compared to the current version in the second half of 2013, contains cosmetic changes concerning:

- in $§ 13$ p. 1, clarifying the method of providing youth training, by adding a wording "by creating and running at least one team in the youth category",

- addition of p. m sounding: "payment by the club applying for admission to the Professional League matches for the club's liabilities related to participation in the professional league - in particular for taking up shares in the share capital of the Manager (hereinafter" Deposit ") in the amount: - 200,000 (two hundred thousand) for clubs applying for participation in professional men's volleyball competition, 100,000 (one hundred thousand) zlotys for clubs applying for participation in professional women's volleyball competition.

The deposit should be paid by the club to the bank account of the Manager no later than until the day of play-off referred to in $\S 17 \mathrm{a}$ of the Regulations. The deposit refund to the club, which will not start the competition in the professional league, will take place after the decision to allow new clubs to enter the professional league according to $\S 15$ p. 5 of the Regulations. "

The presented changes mean a further evolution of regulations related to the development of discipline in the country and increasing its professionalization. From the perspective appearing in the volleyball game AZS UWM S.A. these changes do not require changes. This affects further stabilization by ensuring certainty of 
conditions for development.

\section{Club infrastructure}

Volleyball AZS UWM S.A. as part of its operations, it uses facilities that are not owned by the company. These are mainly objects of the University of Warmia and Mazury in Olsztyn (sports hall, gym, biological and social regeneration rooms), Olsztyn College of them. Józef Rusicki (swimming pool, laboratories of biological regeneration rooms, gymnasium, gymnasium) and the Sports and Recreation Center in Olsztyn (Urania entertainment and sports hall). Recently they intend to reduce the external infrastructure and, in near future, to focus the training and recovery units arount the infrastructure owned by the University of Warmia and Mazury.

\section{Budget and sources of financing}

Ensuring the level of sports spectacle depends mainly on the club's budget and its ability to acquire talented players. The systematic increase in organizational and sporting efficiency is closely related to the stabilization of funding sources. For professional volleyball clubs, the following sources of financing exist:

- funds provided by sponsors in exchange for advertising,

- revenues from the sale of admission tickets for matches,

- revenues from player transfers,

- subsidy funds,

- funds from the organizer of the games (among others due to the use of image rights and media rights),

- funds from the club's business activities,

- donations,

- funds from the sale of gadgets and souvenirs.

In the analyzed period, the club maintained the basic layout of promoted contractors, for whom the division was divided: strategic sponsor, main sponsor, strategic partner and partner. Instead of the strategic partner, supporting sponsors appeared and the category of technical partner was introduced. Entities classified into these groups receive the rights to use the image of the club and players or to place ads in the match environment. The degree of marketing engagement depends on the level of funds transferred. Table 1 presents the classification of donors and their change compared to the original study. 
Table 1. Sponsors and partners of the Piłka Siatkowa AZS UWM S.A.

\begin{tabular}{|c|c|c|}
\hline Category & Sponsor/partner in 2013 & Sponsor/partner in 2017 \\
\hline Strategic Sponsor & Indykpol S.A. & Indykpol S.A. \\
\hline Main Sponsor & $\begin{array}{l}\text { Szynaka Meble Sp. z o.o. } \\
\text { Sklepy Sportowe Olimp } \\
\text { Auto Idea Sp. z o.o. }\end{array}$ & $\begin{array}{l}\text { Galeria Warmińska } \\
\text { Damix Sp. z o.o. } \\
\text { Warmia i Mazury - Urząd } \\
\text { Marszałkowski Województwa } \\
\text { Warmińsko-Mazurskiego } \\
\text { Olsztynie, } \\
\text { Uniwersytet Warmińsko- } \\
\text { Mazurski w Olsztynie. } \\
\text { Piekarnia Tyrolska, } \\
\text { Armatura - Dobrowolski, } \\
\text { Urząd Miasta Olsztyn, }\end{array}$ \\
\hline Strategic Partner & \begin{tabular}{l}
\multicolumn{3}{l}{ Urząd Miasta Olsztyn, } \\
Warmia i Mazury - Urząd \\
Marszałkowski Województwa \\
Warmińsko-Mazurskiego \\
Olsztynie, \\
Uniwersytet Warmińsko-Mazurski \\
w Olsztynie.
\end{tabular} & $\mathrm{n} / \mathrm{a}$ \\
\hline $\begin{array}{l}\text { Supporting } \\
\text { Parner }\end{array}$ & & $\begin{array}{l}\text { Donoria S.A., } \\
\text { Polmlek S.A., } \\
\text { Produs Shop Services sp. z o.o. } \\
\text { Warmiński Bank Spółdzielczy, } \\
\text { Zakład Produkcyjno- } \\
\text { Doświadczalny „Bałcyny” Spółka } \\
\text { z o.o. }\end{array}$ \\
\hline Partner & $\begin{array}{l}\text { Olsztyńska Szkoła Wyższa im. } \\
\text { Józefa Rusickiego, } \\
\text { Hotel Wileński, } \\
\text { Armatura - Dobrowolski, } \\
\text { Warmiński Bank Spółdzielczy, } \\
\text { Piekarnia Tyrolska, } \\
\text { British School, } \\
\text { Restauracja Kasyno, } \\
\text { Gazeta Olsztyńska, } \\
\text { Agencja Ochrony Efekt War-Ma, } \\
\text { Fundacja DrClown, } \\
\text { Polmlek, } \\
\text { Olsztyńsk Zakład Komunalny, } \\
\text { Tewes Bis, } \\
\text { Damix, } \\
\text { Ray Obuwie, } \\
\text { Power Energy Drink. }\end{array}$ & $\begin{array}{l}\text { Dr Vita Sp. z o.o. } \\
\text { EVA Zdrój } \\
\text { Samorząd Studencki UWM w } \\
\text { Olsztynie, } \\
\text { Bartbo, } \\
\text { SportoweFakty.pl } \\
\text { Mercedes Benz Auto-Idea } \\
\text { Olsztyn, } \\
\text { British School, } \\
\text { Olsztyńska Szkoła Wyższa im. } \\
\text { Józefa Rusickiego, } \\
\text { Agencja Ochrony Efekt War-Ma, } \\
\text { Fundacja Dr Clown, } \\
\text { Hotel Wileński, } \\
\text { Gazeta Olsztyńska. }\end{array}$ \\
\hline Technical Partner & $\mathrm{n} / \mathrm{a}$ & Eye Sport \\
\hline
\end{tabular}

Source: Own elaboration 
Despite changes in the layout of partners and sponsors, the club managed to maintain the vast majority of donors. According to the club's authorities, this was influenced by business and sports goals that satisfied contractors. The level of relations, despite the turbulent specificity of the industry, is worked out with the assumption of building long-term cooperation. This increases the stability and control of the budget and makes it easier to set goals for the next game seasons. Changes in the structure of funds from counterparties did not significantly affect the overall structure of the company's revenues. According to data received from the managers, the proportions of revenues over four years have been maintained.

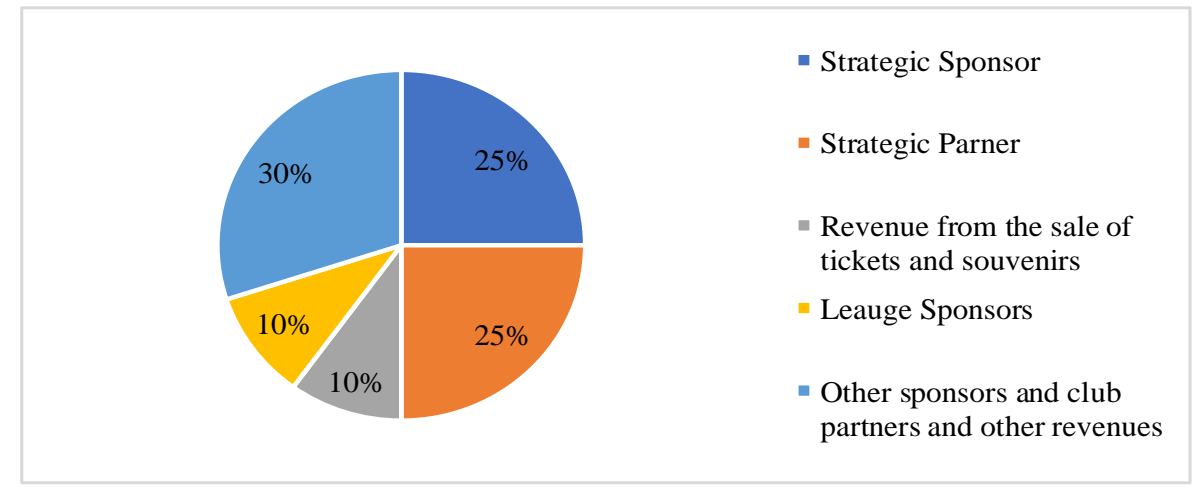

Figure 3. Revenues structure of Piłka Siatkowa AZS UWM S.A. in years 2013-2017 Source: Own elaboration

Due to contractual clauses and the obligation to observe trade secrets, no information on the amount of the budget and the values of its components was obtained during the research. The data obtained on the structure of revenues and costs allows to get a picture of the organization's functioning and its financial condition. The club in 2017 is continuing the strategy of long-term engagement of partners with a decisive contribution to the club's budget. Agreements with other entities are usually signed for one season or a calendar year with the possibility of extension. During the research, the company's cost structure was also analyzed. According to the information analyzed, eighty percent of costs are the costs of the sports division (75\% in 2013). These include, first of all, the costs of players' contracts and training staff, lease and rental of sports infrastructure, organization of the match day, costs related to the provision of social and regeneration facilities (housing, transport, clothing, nutrients). The remaining 20 percent are the costs of running the office, the remuneration of the employees of other employees and the current activity of the club. 


\section{Summary}

Stimulation by the organizer of the games of activities aimed at the development progress of volleyball clubs appearing in the top division (PlusLiga) is manifested mainly in the stabilization of the conditions. Over the past years (2013-2017), there has been no radical change in the requirements but only in the specification of elements that are important in terms of professionalization. The first thing to mention here is the introduction of bail records and the running of a minimum number of youth teams.

The lack of a conditional revolution is one of the aspects of building an effective volleyball club business model. According to the adopted definition of a business model, it helps to describe, characterize and analyze the areas of functioning and environment of a given organization and specify potential sources of competitive advantage by means of a definable bundle of offered value for the client and the value captured by the company. Stability of external conditions creates the possibility of focusing the club's activities on the construction of the offer as much as possible of the value offered to customers and effective interception of its part.

An important determinant of building a business model is a proven work organization, which in the case of Piłka Siatkowa S.A. manifests itself in an almost unchanged form of the organizational structure. The article describes the change of the club's partner portfolio, which, according to the defined business model, has a direct impact on one of its elements, i.e. relationships. Bearing in mind that the presented summary does not present the full profile of cooperators, the presented transformation allows us to accept the conclusion on effective building long-term ties of the analyzed company. In the budget space, Volleyball AZS UWM S.A. it is characterized by significant durability and stability of revenue and cost structures. In the perspective of the global financial crisis from a few years ago, this fact must be appreciated.

The analyzed situation allows us to adopt the conclusion on the effective functioning of Piłka Siatkowa AZS UWM S.A. as a player competing in the business and sports markets. Further research related to the club's business model under the brand name Indykpol AZS Olsztyn, should focus on the analysis of specific areas of the identified business model. A global look at Polish volleyball clubs can be implemented in relation to the presented conditions and the construction of combinations with other units on the market.

\section{References}

Afuah A., Tucci C.L. 2001, Internet Business Models and Strategies: Text and Cases, McGraw-Hill, Boston.

Amit R., Zott Ch. 2001, Value Creation in e-business, Strategic Management Journal, Vol. 22.

Cyfert Sz., Krzakiewicz K. 2011, Wykorzystanie koncepcji modeli biznesu $w$ zasobowej teorii firmy, [w:] Rozwój szkoły zasobowej zarządzania 
strategicznego (red.) R. Krupski, Prace Naukowe Wałbrzyskiej Wyższej Szkoły Zarządzania i Przedsiębiorczości, Wałbrzych.

Klisiński J. 2000, Profesjonalizacja i profesjonaliści $w$ zarządzaniu sportem. Wydawnictwo Politechniki Częstochowskiej. Częstochowa.

Magretta J., 2002, Why Business Models Matter?, Harvard Business Review, Vol. 80 , No 5.

Muszyński M. 2006, Aktywne metody prowadzenia strategii przedsiębiorstwa, Wydawnictwo PLACET, Warszawa.

Nogalski B. 2009, Modele biznesu jako narzędzie reorientacji strategicznej przedsiębiorstw, Master of Business Administration, $\mathrm{nr} 2$.

Osterwalder A., Pigneur Y., Tucci C.L. 2005, Clarifying Business Models: Origins, Present and Future of the Concept, Communications of AIS, Vol. 15.

Sadowski W. 1964, Teoria podejmowania decyzji, PWE, Warszawa.

Vankatraman N., Henderson J.C. 1998, Real strategies for virtual organizing, Sloan Management Review, Vol. 40.

Weill P., Vitale M.R. 2001, Place to Space, Harvard Business School Press, Boston.

Wiśniewski A.K., Zarządzanie Klubem Sportowym Na Przykładzie Indykpolu AZS Olsztyn, Journal of Heallth Sciences. 2013;3(11).

Regulamin Profesjonalnego Wspótzawodnictwa w Piłce Siatkowej Mężczyzn (pol.). plusliga.pl [2017-10-09]. 